Syntax Literate : Jurnal Ilmiah Indonesia p-ISSN: 2541-0849

e-ISSN : 2548-1398

Vol. 5, No. 6, Juni 2020

\title{
FAKTOR-FAKTOR YANG BERHUBUNGAN DENGAN KEJADIAN BERAT BADAN LAHIR RENDAH (BBLR) PADA PETANI BAWANG MERAH DI KECAMATAN KETANGGUNGAN KABUPATEN BREBES PROVINSI JAWA TENGAH TAHUN 2017
}

\section{Ika Popi Sundani}

Program Studi Diploma III Kebidanan Akademi Kebidanan Graha Husada Cirebon

Email: ikapopisundani@gmail.com

\section{Abstract}

$L B W$ is a baby born with a weight less than 2,500 grams regardless of pregnancy period. To determine the causes of $L B W$, conducted an assessment of what risk factors can cause LBW occurrence. Theoretically, factors that influence the occurrence of LBW include maternal factors, fetuses, health services and the environment. The general objective of this research is to know the factors associated with the LBW on onion farmers cases in SubDistrict of Ketanggungan, Brebes Regency, Central Java Province of 2017, including variables of mother's age, mother's education, mother's knowledge, pregnancy age, birth spacing, parity, history of $L B W$ at previous birth, income, nutritional status, frequency of antenatal care examination, participation in agricultural activities, duration of work and use of personal protective equipment. Descriptive analytic research method with case control research design with a sample of 120 mothers who have babies aged $\leq 1$ year. Data analysis was done by univariate, bivariate and multivariate. The results showed that multivariate analysis of duration of work variable $(p=0.006$ OR: $8.117 C I=1.838-35.834)$ became the most dominant variable related to the $L B W$ occurrence. The variable of birth spacing and history of $L B W$ at previous birth have no relation with $L B W$ occurrence.

Keywords: Factor-Factor, Low Birth Weight (LBW), Participation in Agricultural Activities.

\footnotetext{
Abstrak

Berat Badan Lahir Rendah (BBLR) adalah bayi yang lahir dengan berat badan kurang dari 2.500 gram tanpa memandang masa kehamilan. Untuk mengetahui penyebab terjadinya Berat Badan Lahir Rendah (BBLR), dilakukan pengkajian terhadap faktor risiko apa yang dapat menimbulkan terjadinya BBLR. Secara Teori faktor yang mempengaruhi terjadinya BBLR meliputi faktor ibu, janin, pelayanan kesehatan dan lingkungan. Tujuan umum dalam penelitian ini untuk mengetahui faktor-faktor yang berhubungan dengan kejadian BBLR pada petani bawang merah di Kecamatan Ketanggungan Kabupaten Brebes Provinsi Jawa Tengah Tahun 2017, meliputi variabel umur ibu, pendidikan ibu, pengetahuan ibu, usia kehamilan, jarak kelahiran, paritas, riwayat BBLR pada kelahiran sebelumnya, pendapatan, status gizi, frekuensi pemeriksaan antenatal care, keikutsertaan dalam kegiatan pertanian, lama kerja dan penggunaan alat pelindung diri. Metode penelitian deskriptif analitik
} 
dengan desain penelitian case control dengan sampel berjumlah 120 ibu yang mempunyai bayi umur $\leq 1$ tahun. Analisa data dilakukan secara univariat, bivariat dan multivariat. Hasil penelitian menunjukkan pada analisa multivariat variabel lama kerja ( $\mathrm{p}=0.006$ OR: $8.117 \mathrm{CI}=1.838$-35.834) menjadi variabel paling dominan yang berhubungan dengan kejadian BBLR. Variabel jarak kelahiran dan riwayat Berat Badan Lahir Rendah (BBLR) pada kelahiran sebelumnya tidak memiliki hubungan dengan kejadian Berat Badan Lahir Rendah (BBLR).

Kata kunci : Faktor-faktor, BBLR, Keikutsertaan Dalam Kegiatan Pertanian

\section{Pendahuluan}

Indonesia sebagai salah satu negara berkembang memiliki tujuan untuk mensejahterakan rakyatnya. Salah satu bidang yang menjadi prioritas negara berkembang adalah kesejahteraan bidang kesehatan. Kesehatan merupakan salah satu unsur kesejahteraan umum yang harus diwujudkan sesuai dengan cita-cita bangsa Indonesia melalui pembangunan nasional yang berkesinambungan dan diarahkan pada peningkatan derajat kesehatan yang dicerminkan oleh besar kecilnya kematian maternal dan kematian neonatal (Amalia, 2016).

Generasi yang sehat, cerdas dan berkualitas serta penurunan AKB (Angka Kematian Bayi) harus di upayakan sedini mungkin dengan cara pemeliharaan Kesehatan bayi. Salah satu indikator yang lazim digunakan untuk menentukan derajat kesehatan masyarakat adalah AKB. AKB merupakan jumlah kematian bayi ( $0-12$ bulan) per 1.000 kelahiran hidup dalam kurun waktu satu tahun (Profil Dinas Kesehatan Kabupaten Brebes, 2015).

Menurut Word Health Organization (WHO), pada tahun 2009 terdapat 5 juta kematian bayi setiap tahun dan $98 \%$ kematian tersebut terjadi di Negara berkembang. Indonesia sebagai Negara berkembang, masih memiliki AKB yang tinggi sebesar 34 per 1000 kelahiran hidup (Badan Pusat Statistik, 2012). Berdasarkan Profil Dinas Kesehatan Provinsi Jawa Tengah (2015), jumlah kematian bayi di Jawa Tengah mengalami penurunan tetapi tidak signifikan dibandingkan AKB tahun 2014 yaitu 10,08 menjadi 10 per 1.000 kelahiran hidup. AKB Kabupaten Brebes tahun 2015 mengalami penurunan bila dibandingkan tahun 2014 dan bila berdasarkan SDGs (Sustainable Development Goals) ke - 3 tahun 2016 yaitu 25 per 1000 kelahiran hidup, berarti angka kematian di Kabupaten Brebes masih di bawah target (Profil Dinas Kesehatan Kabupaten Brebes, 2015).

Faktor-faktor yang mempengaruhi AKB menurut laporan WHO yang dikutip dari State of the world's mother 2007 di antaranya berat badan lahir rendah (BBLR) yaitu sebesar 27\%. Hasil Survei Demografi Kesehatan Indonesia (SDKI) 2007 penyebab kematian bayi adalah BBLR yaitu sebesar 30,3\%. Bayi dengan BBLR berisiko mengalami kematian 6,5 kali lebih besar daripada bayi yang lahir dengan berat badan normal (Sistiarani, 2008).

Menurut Proverawati dkk. (2010), faktor yang berhubungan dengan bayi BBLR meliputi faktor ibu antara lain penyakit yang dialami ibu saat kehamilan seperti anemia, hipertensi dan preeklampsia, kejadian tertinggi pada ibu umur $<20$ tahun atau $>35$ 
tahun, usia kehamilan yang berisiko yaitu di bawah dari 37 minggu atau lebih dari 42 minggu, jarak kelahiran yang terlalu dekat atau terlalu pendek $<2$ tahun, paritas, riwayat BBLR sebelumnya, keadaan sosial ekonomi (kejadian tertinggi terdapat pada golongan sosial ekonomi rendah), tingkat pendidikan yang rendah, keadaan gizi yang kurang baik, pengawasan antenatal oleh tenaga kesehatan kurang dan sebab lainnya ibu peminum alkohol dan perokok. Pada faktor janin, hidramnion atau kelebihan cairan ketuban, kehamilan kembar/ganda dan kelainan kongenital. Sedangkan dari faktor lingkungan, bertempat tinggal di dataran tinggi, terkena radiasi, terpapar zat beracun dan pestisida termasuk salah satu bahan beracun (Syafitri, Sitawati, \& Setyobudi, 2014).

Pertanian di Indonesia merupakan sektor penyerap paling banyak tenaga kerja. Tahun 2012 diperkirakan oleh Kementerian Pertanian sekitar 50\% perempuan Indonesia ikut andil dalam membangun pertanian. Tercatat sebagian besar perempuan, istri atau ibu, dari 23 juta keluarga petani yang terlibat. Peran perempuan di sektor pertanian yang sangat besar membuat perempuan juga dominan dan paling berisiko terhadap dampak pestisida karena pestisida merupakan salah satu bahan beracun (Syafitri et al., 2014).

Efek negatif dari pajanan pestisida pada kelompok wanita usia subur termasuk ibu hamil dapat menimbulkan berbagai gangguan seperti anemia, disfungsi tiroid dan gangguan reproduksi (abortus spontan, lahir prematur, janin cacat, terjadinya gangguan pertumbuhan psikomotorik anak dan juga BBLR (Siwiendrayanti, 2011).

Menurut Setiyobudi dkk. (2013), besarnya paparan pestisida pada ibu hamil tergantung dari pekerjaan ibu, lama paparan, frekuensi paparan, penyimpanan pestisida, pencampuran pestisida dan penanganan peralatan pestisida serta penggunaan alat pelindung diri. Berdasarkan Data Profil Dinas Pertanian Kabupaten Brebes (2016), Brebes merupakan Kabupaten di Jawa Tengah yang tingkat pemakaian pestisidanya cukup tinggi, karena luasnya lahan pertanian khususnya bawang merah. Brebes yang mempunyai lahan pertanian bawang merah lebih dari 23.000 Ha mempekerjakan ratusan buruh tani perempuan.

Berdasarkan Profil Kesehatan Kabupaten Brebes, angka kejadian BBLR di Kabupaten Brebes setiap tahun mengalami peningkatan. Tahun 2013 sebanyak 1.415, Tahun 2014 sebanyak 1.468 dan pada Tahun 2015 sebanyak 1.572 per 1000 kelahiran bayi. Berdasarkan jumlah bayi baru lahir yang ditimbang sebanyak 33.312 balita, 1.572 balita $(4,72 \%)$ dikategorikan BBLR. Kondisi ini dapat terjadi karena di antaranya dipengaruhi oleh faktor gizi ibu hamil yang kurang baik dan pestisida di lingkungan pertanian tempat tinggal ibu hamil.

Kecamatan dengan Angka kejadian BBLR tertinggi pada tahun 2015 terdapat di Kecamatan Ketanggungan yaitu 189 dari 2.277 bayi lahir hidup dan berdasarkan hasil wawancara dengan petugas lingkungan di Dinas Kesehatan Kabupaten Brebes, menunjukkan Kecamatan Ketanggungan merupakan daerah dengan tingkat penggunaan pestisida tinggi dan intensif. Para petani pada umumnya menggunakan campuran 3-5 jenis pestisida dengan frekuensi menyemprot hampir setiap hari terutama pada musim penghujan.

Berdasarkan Hasil survei awal yang dilakukan di Kecamatan Ketanggungan Kabupaten Brebes Pada Bulan Agustus 2016, menunjukkan perempuan usia subur di 
antaranya ibu hamil ikut serta dalam kegiatan pertanian. Bentuk keikutsertaan ini seperti melepas bawang dari tangkainya, membantu menyiapkan pestisida dan mencuci peralatan/pakaian yang dipakai suami saat menyemprot. Selain itu 30\% dari hasil panen bawang merah yang sebelumnya sudah dilakukan penyemprotan pestisida di simpan di dalam rumah sebagai benih untuk proses penanaman berikutnya.

Berdasarkan data yang diperoleh dari Puskesmas di Kecamatan Ketanggungan pada bulan Januari sampai dengan Desember 2016 terdapat 159 kasus BBLR. Oleh karena itu peneliti ingin mengetahui faktor apa saja yang mempengaruhi kejadian BBLR pada petani bawang merah di Kecamatan Ketanggungan Kabupaten Brebes Provinsi Jawa Tengah Tahun 2017.

\section{Metode Penelitian}

Penelitian ini menggunakan pendekatan kuantitatif dengan desain case control yaitu pendekatan yang mempelajari bagaimana faktor risiko dengan pendekatan "retrospektif" yaitu untuk melihat ke belakang tentang riwayat status paparan penelitian yang dialami oleh objek (Noor, 2008).

Desain penelitian ini untuk mengetahui hubungan antara variabel independen dan variabel dependen berdasarkan perjalanan waktu secara retrospektif. Penelitian dimulai dengan mengukur variabel dependen, kemudian membagi subyek penelitian menjadi 2 kelompok yaitu kasus (BBLR) dan Kontrol (Tidak BBLR/Normal). Selanjutnya peneliti mengukur variabel independen (faktor penyebab BBLR) yang terjadi pada responden dimasa lalu secara retrospektif. Kejadian dimasa lalu diidentifikasi melalui studi dokumentasi atau pengkajian riwayat masa lalu responden.

\section{Hasil Dan Pembahasan}

\section{Kejadian Berat Badan Lahir Rendah}

Berdasarkan hasil penelitian dari 120 ibu yang memiliki bayi umur $\leq 1$ tahun diketahui bahwa sebagian besar responden yang mengalami kejadian bayi dengan BBLR berada pada umur $<20$ tahun yaitu 14 (46.7\%), sedangkan sebagian besar responden pada kelompok umur 20-35 tahun tidak mengalami kejadian bayi BBLR sejumlah $56(62.2 \%)$. Artinya hasil penelitian ini menunjukkan bahwa kejadian BBLR disebabkan oleh faktor umur responden yang sebagian dalam kategori tidak reproduktif.

Menurut (Manuaba \& Bagus, 2007), umur <20 tahun dianggap sangat berbahaya untuk hamil, karena secara fisik tubuh ibu masih dalam pertumbuhan dan organorgan reproduksi masih sangat muda dan belum kuat, belum sempurnanya peredaran darah yang menuju uterus dan serviks, sehingga hal tersebut dapat mengganggu proses masuknya nutrisi ke janin yang ada dalam kandungan dan berat bayi kurang normal pun bisa terjadi. Sedangkan menurut Saiffudin (2005) umur 2035 tahun adalah kelompok umur yang dianggap paling baik untuk kehamilan, sebab selain fisik sudah cukup kuat, dari segi mental pun sudah cukup dewasa.

Selain faktor umur, paritas responden pun mempengaruhi kejadian BBLR, diketahui sebanyak (53.3\%) responden yang melahirkan secara prematur mengalami 
kejadian BBLR, pendidikan yang rendah dan frekuensi pemeriksaan ANC yang kurang berpengaruh terhadap pengetahuan ibu tentang BBLR juga kurang, status gizi yang kurang karena pendapatan yang rendah serta keterlibatan ibu dalam kegiatan pertanian yang dilakukan lebih dari tiga kali dalam seminggu tanpa penggunaan alat pelindung diri.

Menurut teori Blum (1981) dalam penelitian (Damanik \& Gorodetski, 2011) status kesehatan masyarakat dipengaruhi secara simultan oleh empat faktor penentu yang saling berinteraksi satu sama lain. Keempat faktor tersebut adalah lingkungan, perilaku, pelayanan kesehatan dan keturunan. Konsep itu menunjukkan bahwa status kesehatan termasuk kejadian bayi dengan berat badan lahir rendah dipengaruhi oleh faktor lingkungan, perilaku, pelayanan kesehatan dan faktor keturunan. Faktor lingkungan antara lain lingkungan fisik, biologis dan sosial memegang peranan yang terbesar dimana hampir sebagian besar lingkungan fisik di Kecamatan Ketanggungan Kabupaten Brebes merupakan pertanian bawang merah dengan penggunaan pestisidanya cukup tinggi serta keterlibatan para wanita cukup besar dalam kegiatan ini. Keadaan masyarakat dengan pendapatan dan status gizi yang rendah, pengetahuan yang kurang serta pendidikan yang rendah yang hampir sebagian responden hanya menamatkan sekolah sampai SD dan SMP yaitu sejumlah $(74.2 \%)$.

\section{Umur Ibu}

Berdasarkan hasil penelitian didapatkan bahwa, dari responden yang mengalami kejadian BBLR, ada sejumlah 14 responden $(46.7 \%)$ berumur $<20$ tahun. Sedangkan pada kelompok responden yang tidak mengalami kejadian BBLR, ada sejumlah 20 responden $(22.2 \%)$ yang berumur $<20$ tahun. Dari hasil tersebut secara persentase, ibu yang berumur $<20$ tahun lebih banyak yang melahirkan bayi dengan BBLR dibandingkan dengan ibu yang melahirkan bayi tidak BBLR (BBLN). Hasil uji statistik hubungan antara umur ibu dengan kejadian BBLR diperoleh nilai $\mathrm{p}=0.007$ maka dapat disimpulkan ada hubungan yang signifikan antara umur ibu dengan kejadian BBLR.

Untuk mendapatkan nilai OR peneliti melakukan dummy pada tiga kategori umur ibu ini, sehingga dapat pula dilihat kategori umur mana yang mempunyai risiko lebih besar untuk mengalami kejadian BBLR.

Berdasarkan tabel dummy umur tersebut diketahui bahwa nilai OR pada dummy umur $<20$ dan $\geq 20$ tahun sebesar 3.063 sedangkan pada dummy umur $>35$ dan $\leq 35$ tahun didapatkan nilai OR sebesar 1.652 sehingga dapat disimpulkan bahwa pada kategori umur $<20$ tahun memiliki risiko 3 kali lebih besar untuk mengalami kejadian BBLR.

Kehamilan di bawah umur 20 tahun merupakan kehamilan yang berisiko tinggi. Angka kematian dan kesakitan ibu pun 2-4 kali dibandingkan dengan ibu yang hamil dengan usia yang cukup dewasa. Pada umur tersebut fungsi dari alat reproduksi belum siap, sehingga mengakibatkan banyak risiko (Trihardiani, 2011).

Umur ibu mempengaruhi tingkat kejadian Berat Badan Lahir Rendah (BBLR), terutama ibu dengan paritas tinggi yaitu umur ibu kurang dari 20 tahun, 
pada umur ibu yang terlalu muda (kurang dari 20 tahun) peredaran darah menuju serviks dan juga uterus masih belum sempurna sehingga ini dapat mengganggu proses penyaluran nutrisi dari ibu ke janin yang dikandungnya (Manuaba, 2010). Selain dari segi fisik dan reproduksi yang belum siap untuk hamil, umur $<20$ tahun secara psikologi juga belum matang. Menurut Jean Jacques Rousseau dalam buku (Soekanto, 2002). masa pematangan diri terlihat ketika individu berumur lebih dari 20 tahun. Dalam tahap ini, perkembangan fungsi kehendak mulai dominan. Orang mulai dapat membedakan mana yang harus dilakukan untuk kesehatannya dalam hal ini menjaga kesehatan diri dan janin yang dikandungnya selama kehamilan.

BBLR juga meningkat seiring dengan penambahan usia ibu, dengan peningkatan usia ibu maka akan terjadi perubahan pada pembuluh darah disertai dengan menurunnya fungsi hormon yang mengatur siklus reproduksi (endometrium). Di samping itu, semakin bertambahnya umur maka akan semakin meningkatkan pula risiko hipertensi yang juga merupakan faktor predisposisi terjadinya BBLR (Sondari, SYAMSUR1PUTRA, \& Setiadi, 2006). Secara psikologi pada usia > 35 tahun kemampuan diri dan kematangan emosional lebih stabil, pengalaman dalam kehamilan dan perawatan bayi jauh lebih baik sehingga kejadian BBLR masih dapat dicegah. Umur 2035 tahun adalah kelompok umur yang paling baik untuk kehamilan, sebab selain fisik sudah cukup kuat, dari segi mental wanita tersebut sudah cukup dewasa dan mampu merawat bayi dan dirinya sendiri (Martaadisoebrata, Sastrawinata, \& Saifuddin, 2005).

Hasil penelitian ini sesuai dengan penelitian yang dilakukan oleh Suhaili di Rumah Sakit Hasan Sadikin Bandung pada Tahun 2003, memperlihatkan adanya hubungan yang bermakna antara kejadian BBLR dengan usia ibu di mana nilai $\mathrm{p}$ $0.003<0.05$. Selain itu penelitian ini juga diperkuat oleh penelitian yang telah dilakukan oleh (Sistiarani, 2008), yang menunjukkan adanya perbedaan yang signifikan persentase BBLR antara ibu yang termasuk kategori umur yang berisiko dengan ibu yang termasuk kategori umur yang tidak berisiko pada saat hamil dan melahirkan. Hasil uji statistik yang didapatkan nilai p $0.009<0.05, \mathrm{OR}=4.28(95 \%$ CI : 1.4-12.4) artinya ibu yang termasuk kategori umur berisiko (umur kurang dari 20 tahun) mempunyai peluang melahirkan BBLR 4,28 kali dibandingkan ibu yang tidak termasuk kategori umur yang tidak berisiko (umur 20 tahun sampai dengan 35 tahun).

\section{Pendidikan Ibu}

Berdasarkan hasil penelitian didapatkan bahwa, dari responden yang mengalami kejadian BBLR, ada sejumlah 28 responden (93.3\%) berpendidikan rendah. Sedangkan pada kelompok responden yang tidak mengalami kejadian BBLR, ada sejumlah 61 responden (67.8\%) yang berpendidikan rendah. Dari hasil tersebut secara persentase, ibu yang berpendidikan rendah lebih banyak yang melahirkan bayi dengan BBLR dibandingkan dengan ibu yang melahirkan bayi tidak BBLR (BBLN). Hasil uji statistik hubungan antara pendidikan ibu dengan kejadian BBLR diperoleh nilai $\mathrm{p}=0.011$ maka dapat disimpulkan ada hubungan yang signifikan antara pendidikan ibu dengan kejadian BBLR. Diperoleh pula nilai OR= 6.656 (95\% CI; 
1.483 - 29.862) dapat diartikan bahwa ibu yang mempunyai pendidikan rendah, memiliki peluang melahirkan bayi dengan BBLR 7 kali dibandingkan dengan ibu yang berpendidikan tinggi.

Hasil penelitian ini sesuai dengan penelitian yang dilakukan oleh (NURROHMAH, 2002), yang menyatakan bahwa variabel yang mempunyai hubungan secara bermakna dengan kejadian BBLR yaitu salah satunya pendidikan di mana berdasarkan hasil uji didapatkan nilai $p$ value $=0.017$ dan $\mathrm{OR}: 3.755$ yang artinya ibu yang memiliki pendidikan rendah mempunyai peluang 3.755 kali untuk mengalami kejadian BBLR. Begitu pula dengan penelitian yang dilakukan (Nurhadi, 2006), Proporsi kejadian BBLR pada ibu hamil yang berpendidikan formal 6 tahun, lebih besar dibandingkan dengan ibu yang melahirkan bayi dengan berat lahir normal pada ibu yang berpendidikan rendah.

Menurut (Setyaningrum, Triyanti, \& Indrawani, 2014), pendidikan adalah salah satu tolak ukur status ekonomi yang mempengaruhi outcame pelayanan kesehatan. Wanita pun dipandang perlu berpendidikan tinggi, dengan pendidikan tinggi taraf hidup mereka dapat meningkat, membuat keputusan yang terutama menyangkut masalah Kesehatan dan berbeda dengan wanita yang berpendidikan rendah dimana wanita berpendidikan tinggi dapat berperilaku sehar dalam kehidupan sehari-hari. Semakin tinggi tingkat pendidikan seseorang wanita maka ia semakin tinggi pula tingkat kesadaran tentang sesuatu hal dan semakin matang pertimbangan seseorang untuk mengambil sebuah keputusan. Pendidikan banyak menentukan sikap dan tindakan dalam menghadapi berbagai masalah misalnya membutuhkan vaksinasi untuk anaknya, memberi oralit waktu mencret, kesediaan menjadi peserta keluarga, termasuk pengaturan makanan bagi ibu hamil untuk mencegah timbulnya bayi BBLR.

Tingkat pendidikan mempengaruhi kesadaran akan pentingnya arti kesehatan diri, individu dan lingkungannya yang dapat mempengaruhi atau mendorong kebutuhan akan pelayanan kesehatan. Khususnya tingkat pendidikan ibu yang sangat berpengaruh terhadap kualitas pengasuhan anak. Pesan kesehatan akan sulit dicerna jika tingkat pendidikan seorang ibu rendah. Tingkat pendidikan yang lebih tinggi akan memudahkan seseorang untuk menyerap informasi dan mengimplementasikannya dalam perilaku dan gaya hidup sehari-hari (Depkes, 2007)

Dalam penelitian ini dapat diketahui bahwa angka kejadian bayi dengan BBLR maupun tidak BBLR berada pada ibu dengan tingkat pendidikan rendah. Hal ini diketahui dari jumlah responden yang sebagian besar merupakan ibu dengan pendidikan rendah yaitu SD (49.2\%) dan SMP (25\%).

\section{Pengetahuan Ibu}

Berdasarkan hasil penelitian didapatkan bahwa, dari responden yang mengalami kejadian BBLR, ada sejumlah 23 responden $(76.7 \%)$ berpengetahuan kurang. Sedangkan pada kelompok responden yang tidak mengalami kejadian BBLR, ada sejumlah 38 responden (42.2\%) yang berpengetahuan kurang. Dari hasil tersebut secara persentase, ibu yang berpengetahuan kurang lebih banyak yang melahirkan bayi BBLR, dibandingkan dengan ibu yang melahirkan bayi tidak BBLR 
(BBLN). Hasil uji statistik hubungan antara pengetahuan dengan kejadian BBLR diperoleh nilai $\mathrm{p}=0.002$ maka dapat disimpulkan ada hubungan yang signifikan antara pengetahuan dengan kejadian BBLR. Diperoleh pula nilai OR $=4.496(95 \%$ CI; 1.750 - 11.554) dapat diartikan bahwa ibu yang mempunyai pengetahuan kurang, memiliki peluang melahirkan bayi dengan BBLR 4.5 kali dibandingkan dengan ibu yang berpengetahuan baik. Hal ini sejalan dengan hasil penelitian Nurohmah (2002), dari hasil penelitian menjelaskan bahwa ada hubungan yang signifikan antara pengetahuan ibu dengan kejadian BBLR dengan nilai $p$ value $0.002<0.05$ dan mereka yang mempunyai pengetahuan kurang tentang ANC mempunyai peluang 4.7 kali untuk mengalami Kejadian BBLR.

Besarnya tingkat pengetahuan yang kurang di objek penelitian berdasarkan hasil observasi ditemukan bahwa sebagian ibu belum mengenal dan mengetahui tentang perilaku kesehatan dan kehamilan. Sebagian besar ibu belum mengetahui bagaimana menjaga nutrisi yang baik selama hamil, tanda bahaya pada ibu hamil termasuk bahaya dari pestisida yang ada di sekitarnya yang dapat menimbulkan pengaruh terhadap kehamilan dan janin yang ada dalam kandungannya. Kaitannya dengan pemeriksaan ANC yang sebetulnya dapat banyak memberikan ilmu dan informasi terkait kesehatan ibu dan bayi sebagian besar responden kurang memanfaatkannya. Hal ini dibuktikan dengan hasil frekuensi pemeriksaan ANC kurang pada sebagian besar responden $(57.5 \%)$.

Penelitian ini juga sependapat dengan Soetriono (2007), pengetahuan merupakan aspek pokok untuk menentukan perilaku untuk menyadari dan tidak, maupun mengatur perilakunya sendiri. Tahu' kerap kali menjadi dasar suatu tindakan. Timbulnya gangguan kesehatan atau penyakit pada seseorang disebabkan oleh perilaku seseorang tersebut. Pengetahuan tentang BBLR maupun pestisida dalam pertanian adalah hasil dari 'tahu' seseorang, yang terjadi setelah orang tersebut melakukan pengindraan terhadap kejadian BBLR.

\section{Usia Kehamilan}

Berdasarkan hasil penelitian menunjukkan bahwa, dari responden yang mengalami kejadian BBLR, ada sejumlah 20 responden $(66.7 \%)$ dengan usia kehamilan berisiko. Sedangkan pada kelompok responden yang tidak mengalami kejadian BBLR, ada sejumlah 39 responden (43.3\%) dengan usia kehamilan berisiko. Dari hasil tersebut secara persentase, ibu dengan usia kehamilan berisiko lebih banyak yang melahirkan bayi dengan BBLR dibandingkan dengan ibu yang melahirkan bayi tidak BBLR (BBLN). Hasil uji statistik hubungan antara usia kehamilan dengan kejadian BBLR diperoleh nilai $\mathrm{p}=0.045$ maka dapat disimpulkan ada hubungan yang signifikan antara usia kehamilan dengan kejadian BBLR. Diperoleh pula nilai $\mathrm{OR}=2.615(95 \% \mathrm{CI} ; 1.100-6.218)$ dapat diartikan bahwa ibu yang mempunyai usia kehamilan berisiko, memiliki peluang melahirkan bayi BBLR 3 kali dibandingkan dengan ibu yang mempunyai usia kehamilan tidak berisiko.

Hal ini sejalan dengan hasil penelitian Farika (2016), ibu yang melahirkan pada umur kehamilan kurang dari 37 minggu memiliki risiko 10 kali lebih besar untuk mengalami BBLR dibandingkan dengan ibu yang melahirkan pada umur $\geq 37$ 
minggu. Penelitian ini didukung pula dengan penelitian Dwiningsih (2007), diketahui bahwa dari 298 kasus BBLR terdapat 229 (76.8\%) yang dipengaruhi oleh usia kehamilan ibu bersalin dengan $p$ value $0.04<0.05$ yang menunjukkan bahwa terdapat hubungan yang bermakna antara usia kehamilan ibu bersalin dengan kejadian BBLR. Penelitian ini sesuai pula dengan teori yang ditulis oleh (Pantiawati, 2010), yang menyatakan bahwa penentuan usia kehamilan sangat penting karena angka kematian dan kesakitan menurun dengan meningkatnya umur kehamilan. Selain itu, ada hubungan antara umur kehamilan dan tingkat maturitas fisiologis neonatus.

Bayi lahir prematur adalah bayi yang lahir dengan usia kehamilan antara 2836 minggu. Bayi prematur dengan kategori kurang bulan ini organ dan alat-alat tubuhnya belum bisa berfungsi secara optimal ketika hidup di luar rahim sang ibu. Semakin muda usia kehamilan, maka semakin rentan organ bayi dan prognosisnya juga buruk. Sedangkan pada bayi matur, organ dan alat-alat tubuh bayi sudah matang dan berfungsi lebih baik dibanding dengan bayi kurang bulan.

Sedangkan menurut Utomo (1985) dalam penelitian (Nurhadi, 2006), bayi BBLR dengan berat lahir sesuai menurut umur kehamilan biasanya berhubungan dengan kejadian ketidakmampuan uterus untuk mempertahankan janin. Kontraksi efektif pada uterus sebelum kelahiran yang belum mencapai usia kehamilan disebabkan karena gangguan pada perjalanan kelahiran. Kelahiran preterm disebabkan karena adanya infeksi oleh bakteri pada cairan amnion dan ketuban. Produk-produk bakteri dapat merangsang produksi sitokinin lokal dengan akibat ketuban pecah setempat.

\section{Jarak kelahiran}

Berdasarkan hasil penelitian menunjukkan bahwa, dari responden yang mengalami kejadian BBLR, ada sejumlah 17 responden (56.7\%) dengan jarak kelahiran tidak berisiko. Sedangkan pada kelompok responden yang tidak mengalami kejadian BBLR, ada sejumlah 61 responden (67.8\%) dengan jarak kelahiran tidak berisiko. Dari hasil tersebut secara persentase, ibu yang mempunyai jarak kelahiran tidak berisiko lebih banyak yang melahirkan bayi tidak dengan BBLR (BBLN) dibandingkan dengan ibu yang melahirkan bayi BBLR. Hasil uji statistik hubungan antara jarak kelahiran dengan kejadian BBLR diperoleh nilai $\mathrm{p}=0.377$ maka dapat disimpulkan tidak ada hubungan yang signifikan antara jarak kelahiran dengan kejadian BBLR

Hasil penelitian ini sejalan dengan penelitian yang dilakukan Fitri (2013), dengan perhitungan statistik menggunakan Chi Square terhadap variabel jarak kelahiran diperoleh nilai $p$ value $=0.070$. Hal ini menunjukkan bahwa tidak ada hubungan yang signifikan antara jarak kelahiran dengan kejadian BBLR.

(Ismi Trihardiani, 2011) dalam penelitiannya menunjukkan hasil yang sama, dari analisis hubungan antara jarak kelahiran dengan kejadian BBLR diperoleh bahwa ada sebanyak $(14,3 \%)$ subyek yang memiliki jarak kelahiran kurang dari sama dengan dua tahun (risiko) melahirkan bayi BBLR, sedangkan di antara subyek yang memiliki tinggi jarak kelahiran lebih dari sama dengan dua tahun (tidak risiko), ada 
$(85,7 \%)$ subyek yang melahirkan bayi BBLR. Hasil uji statistik diperoleh nilai $\mathrm{p}=0,496$ maka dapat disimpulkan tidak ada hubungan antara jarak kelahiran dengan kejadian BBLR.

Jarak kelahiran yang pendek ( $<2$ tahun) akan menyebabkan seorang ibu belum cukup waktu untuk memulihkan kondisi tubuhnya setelah melahirkan sebelumnya. Sistem reproduksi yang terganggu akan menghambat pertumbuhan dan perkembangan janin yang dikandungnya sehingga berpengaruh terhadap berat badan lahir. Ibu hamil yang jarak kelahirannya kurang dari dua tahun, kesehatan fisik dan kondisi rahimnya masih butuh istirahat yang cukup. Ada kemungkinan juga ibu masih menyusui dan memberikan perhatian pada anak yang dilahirkan sebelumnya, sehingga kondisi ibu yang lemah ini akan berdampak pada kesehatan janin dan berat badan lahir (Bobak, Dejmek, Solansky, \& Sram, 2005).

Berdasarkan temuan di lapangan mayoritas responden tidak mempunyai risiko pada jarak kelahiran, baik pada ibu yang mengalami kejadian BBLR maupun tidak BBLR sejumlah (65\%). Tetapi ditemukan bahwa banyaknya ibu yang melahirkan bayi normal berada pada kelahiran lebih dari dua tahun mempunyai persentase lebih tinggi (67.8\%).

\section{Paritas}

Berdasarkan hasil penelitian menunjukkan bahwa, dari responden yang mengalami kejadian BBLR, ada sejumlah 16 responden (53.3\%) dengan paritas berisiko. Sedangkan pada kelompok responden yang tidak mengalami kejadian BBLR, ada sejumlah 13 responden (14.4\%) dengan paritas berisiko. Dari hasil tersebut secara persentase, ibu dengan paritas berisiko lebih banyak yang melahirkan bayi dengan BBLR dibandingkan dengan ibu yang melahirkan bayi tidak BBLR (BBLN). Hasil uji statistik hubungan antara paritas dengan kejadian BBLR diperoleh nilai $\mathrm{p}=0.000$ maka dapat disimpulkan ada hubungan yang signifikan antara paritas dengan kejadian BBLR. Diperoleh pula nilai OR=6.769 (95\% CI; $2.678-17.110$ ) dapat diartikan bahwa ibu yang mempunyai paritas berisiko, memiliki peluang melahirkan bayi BBLR 7 kali dibandingkan dengan ibu yang mempunyai paritas tidak berisiko.

Hasil penelitian ini sejalan dengan penelitian yang dilakukan oleh Nurrohmah (2002), paritas berhubungan secara signifikan dengan kejadian BBLR di mana nilai $p$ value $=0.006$ dan OR: 12.429 (CI: 1.461-105.737).

Paritas yang berisiko melahirkan BBLR adalah paritas lebih dari empat. Setelah seorang ibu melahirkan lebih dari empat dan mempunya paritas tinggi dapat menyebabkan gangguan pada uterus terutama pada fungsi pembuluh darah. Terlalu seringnya kehamilan akan mengakibatkan rusaknya dinding pembuluh darah uterus, dengan demikian hal tersebut dapat menghalangi jalannya nutrisi bagi kehamilan pada janin berikutnya dan karena hal tersebut bayi dengan BBLR lahir.

Kehamilan yang optimal adalah kehamilan anak ke 2-4, ini merupakan paritas paling aman ditinjau dari sudut kematian maternal, hal ini dikarenakan risiko komplikasi yang serius, seperti perdarahan dan infeksi meningkat secara bermakna mulai dari persalinan yang ke empat dan seterusnya, sehingga ada kecenderungan 
bayi lahir dengan kondisi BBLR bahkan terjadinya kematian ibu dan bayi (Winkjosastro, 2005).

Penelitian lain menunjukkan bahwa berat badan lahir bayi meningkat seiring peningkatan status paritas dan mencapai berat badan maksimal pada paritas ketiga, kemudian pada paritas berikutnya rata-rata berat badan bayi akan menurun (Negi, Kandpal, \& Kukreti, 2006). Penelitian lain menambahkan bahwa status paritas yang tinggi dapat meningkatkan risiko kejadian BBLR dan bayi lahir mati. Hal tersebut terjadi karena semakin tinggi status paritasnya maka kemampuan rahim untuk menyediakan nutrisi bagi kehamilan selanjutnya semakin menurun sehingga penyaluran nutrisi antara ibu dan janin terganggu yang akhirnya dapat mengakibatkan BBLR (Aliyu et al., 2005).

\section{Riwayat BBLR Pada Kelahiran Sebelumnya}

Berdasarkan hasil penelitian didapatkan bahwa, dari responden yang mengalami kejadian BBLR, ada sejumlah 16 responden (53.3\%) dengan tidak berisiko pada riwayat BBLR kelahiran sebelumnya. Sedangkan pada kelompok responden yang tidak mengalami kejadian BBLR, ada sejumlah 56 responden (62.2\%) dengan tidak berisiko pada riwayat BBLR kelahiran sebelumnya. Dari hasil tersebut secara persentase, ibu tidak berisiko pada riwayat BBLR kelahiran sebelumnya lebih banyak yang melahirkan bayi tidak dengan BBLR (BBLN) dibandingkan dengan ibu yang melahirkan bayi BBLR. Hasil uji statistik hubungan antara riwayat BBLR pada kelahiran sebelumnya dengan kejadian BBLR diperoleh nilai $\mathrm{p}=0.519$ maka dapat disimpulkan tidak ada hubungan yang signifikan antara riwayat BBLR pada kelahiran sebelumnya dengan kejadian BBLR.

Hasil penelitian ini tidak sejalan dengan penelitian Saraswati (2001), yang menyatakan bahwa ibu hamil yang pernah melahirkan bayi BBLR dan lahir mati mempunyai risiko untuk melahirkan bayi BBLR 4,35 kali lebih tinggi dibandingkan ibu yang tidak pernah melahirkan bayi lahir mati. Ibu yang mempunyai riwayat BBLR sebelumnya lebih berisiko terjadi BBLR pada kehamilan dan persalinan berikutnya (Proverawati, n.d.)

Hal ini dikarenakan dari data yang didapatkan mayoritas responden tidak mengalami kejadian BBLR pada kehamilan sebelumnya sejumlah (60\%). Namun hal ini tidak membuktikan bahwa riwayat BBLR pada kelahiran sebelumnya selalu mempunyai risiko atau mempengaruhi kelahiran berikutnya karena berdasarkan hasil temuan menunjukkan bahwa persentase lebih besar pada ibu yang melahirkan dengan berat badan bayi normal tidak mempunyai riwayat BBLR pada kelahiran sebelumnya sejumlah $(62.2 \%)$.

\section{Pendapatan}

Berdasarkan hasil penelitian didapatkan bahwa, dari responden yang mengalami kejadian BBLR, ada sejumlah 22 responden $(73.3 \%)$ dengan pendapatan rendah. Sedangkan pada kelompok responden yang tidak mengalami kejadian BBLR, ada sejumlah 43 responden (47.8\%) dengan pendapatan rendah. Dari hasil tersebut secara persentase, ibu dengan pendapatan rendah lebih banyak yang melahirkan bayi dengan BBLR dibandingkan dengan ibu yang melahirkan bayi tidak BBLR (BBLN). 
Hasil uji statistik hubungan antara pendapatan dengan kejadian BBLR diperoleh nilai $\mathrm{p}=0.026$ maka dapat disimpulkan ada hubungan yang signifikan antara pendapatan keluarga dengan kejadian BBLR. Dari hasil analisis diperoleh pula nilai OR=3.006 (95\% CI; 1.211-7.458) dari kejadian BBLR. Dapat diartikan bahwa ibu dengan pendapatan rendah, memiliki peluang melahirkan bayi dengan BBLR 3.006 kali dibandingkan ibu dengan pendapatan tinggi.

Hasil penelitian Zaenab 2006 menyatakan bahwa rendahnya pendapatan akan menyebabkan kecenderungan ibu kekurangan asupan nutrisi selama kehamilan sehingga menimbulkan gizi buruk. Gizi buruk menyebabkan janin kekurangan zatzat yang dibutuhkan sehingga mengganggu pertumbuhan dan perkembangan yang pada akhirnya dapat menyebabkan BBLR dan bayi cacat. Hal ini sesuai pula dengan teori bahwa, keadaan sosial ekonomi mempengaruhi kualitas dan kuantitas gizi ibu selama bulan-bulan terakhir kehamilan dan ukuran bayi pada saat lahir. Semakin buruk gizi ibu semakin kurang berat dan panjang bayinya (Sistiarani, 2008).

Faktor pendapatan keluarga berhubungan pula dengan tingkat pendidikan, pekerjaan ibu, ekonomi keluarga. Secara tidak langsung, Pendidikan berpengaruh terhadap kehamilan terutama pada kelahiran bayi BBLR. Hal tersebut dikaitkan dnegan Pendidikan seorang ibu yang mengatahui cara merawat dan memelihara kandungan serta upaya dalam pemeriksaan dan mendapatkan pelayanan kesehatan selama ibu tersebut mengandung. Pendapatan keluarga dapat menunjang gambaran kemampuan keluarga dalam memenuhi kebutuhan gizi ibu selama hamil yang berperan terhadap timbulnya prematuritas. Kejadian tertinggi terdapat pada golongan pendapatan rendah (Maryanti, n.d.).

\section{Status Gizi Ibu}

Berdasarkan hasil penelitian didapatkan bahwa, dari responden yang mengalami kejadian BBLR, ada sejumlah 24 responden $(80 \%)$ dengan status gizi kurang. Sedangkan pada kelompok responden yang tidak mengalami kejadian BBLR, ada sejumlah 43 responden (47.8\%) dengan status gizi kurang. Dari hasil tersebut secara persentase, ibu dengan status gizi kurang lebih banyak yang melahirkan bayi dengan BBLR dibandingkan dengan ibu yang melahirkan bayi tidak BBLR (BBLN). Hasil uji statistik hubungan antara status gizi ibu dengan kejadian BBLR diperoleh nilai $\mathrm{p}=0.004$ maka dapat disimpulkan ada hubungan yang signifikan antara status gizi ibu dengan kejadian BBLR. Dari analisis diperoleh pula nilai $\mathrm{OR}=4.372(95 \% \mathrm{CI} ; 1.632-11.714)$. Dapat diartikan bahwa ibu dengan status gizi kurang, memiliki peluang melahirkan bayi dengan BBLR 4.372 kali dibandingkan ibu dengan status gizi baik.

Hasil penelitian ini sejalan dengan hasil penelitian (Shanklin, 1979) dalam penelitian (Nurhadi, 2006) yang menyatakan bahwa, ibu hamil dengan gizi kurang akan melahirkan bayi BBLR 10 kali lebih besar dibandingkan dengan ibu yang gizinya baik. Asupan gizi yang kurang ini juga ditemukan pada penelitian di Ciawi di mana angka kejadian BBLR sebesar 16,1 \%, di daerah ini terdapat kepercayaan tidak makan banyak untuk menghindari bayi besar agar persalinan dapat berjalan lancar. 
Kurangnya gizi berdampak buruk terhadap janin seperti prematuritas, kelahiran mati atau kematian noental dini dan gangguan pertumbuhan janin. Status nutrisi ibu mempunyai efek kevil terhadap pertimbuhan janin selama embriogenetis. Kekurangan gizi saat hamil akan berakibat buruk terhadap janin seperti prematuritas, gangguan pertumbuhan janin, kelahiran mati atau kematian neonatal dini. Selama embriogenesis status nutrisi ibu memiliki efek yang kecil terhadap pertumbuhan janin. Hal ini sesuai dengan perkiraan kebanyakan wanita memiliki simpanan nutrisi yang cukup untuk embrio yang tumbuh lambat. Namun demikian pada fase pertumbuhan trimester III saat hipertrofi sel janin dimulai, kebutuhan nutrisi janin dapat melebihi persediaan ibu jika masukan nutrisi kurang.

Pengaruh gizi terhadap kehamilan sangat penting. Peningkatan pendidikan mengenai gizi dan perolehan gizi yang memadai dari segi susunan menu maupun jumlah atas kualitasnya, hal tersebut yang perlu di perhatikan bagi ibu hamil dengan gizi buruk. Karena adanya malnutrisi pada ibu hamil, menyebabkan volume darah menjadi kurang, aliran darah ke uterus dan plasenta berkurang, ukuran plasenta berkurang dan transfer nutrient melalui plasenta berkurang sehingga janin tumbuh lambat atau terganggu. Ibu hamil dengan kekurangan gizi cenderung melahirkan prematur atau BBLR (Romauli, 2011).

\section{Frekuensi Pemeriksaan ANC}

Berdasarkan hasil penelitian menunjukkan bahwa, dari responden yang mengalami kejadian BBLR, ada sejumlah 25 responden $(83.3 \%$ ) dengan frekuensi pemeriksaan ANC kurang. Sedangkan pada kelompok responden yang tidak mengalami kejadian BBLR, ada sejumlah 44 responden (69\%) dengan frekuensi pemeriksaan ANC kurang. Dari hasil tersebut secara persentase, ibu dengan frekuensi pemeriksaan ANC kurang lebih banyak yang melahirkan bayi dengan BBLR dibandingkan dengan ibu yang melahirkan bayi tidak BBLR (BBLN). Hasil uji statistik hubungan antara frekuensi pemeriksaan antenatal care dengan kejadian BBLR diperoleh nilai $\mathrm{p}=0.002$ maka dapat disimpulkan ada hubungan yang signifikan antara frekuensi pemeriksaan antenatal care dengan kejadian BBLR. Dari analisis diperoleh pula nilai $\mathrm{OR}=5.227(95 \% \mathrm{CI} ; 1.838-14.868)$. Dapat diartikan bahwa ibu dengan frekuensi pemeriksaan ANC kurang, memiliki peluang melahirkan bayi dengan BBLR 5.227 kali dibandingkan ibu dengan pemeriksaan ANC baik.

Hasil penelitian ini sejalan dengan penelitian yang dilakukan oleh (Sistiarani, 2008) yang menyatakan bahwa frekuensi pemeriksaan Antenatal Care mempunyai hubungan yang signifikan dengan kejadian BBLR, ditunjukkan dengan nilai $\mathrm{p}=0.001$ dan OR: 5.85 yang artinya ibu yang tidak melakukan pemeriksaan ANC mempunyai peluang 5.85 kali untuk mengalami kejadian BBLR.

Pelayanan yang dilakukan secara rutin juga merupakan upaya untuk melakukan deteksi dini kehamilan berisiko sehingga dapat dengan segera dilakukan tindakan yang tepat untuk mengatasi dan merencanakan serta memperbaiki kehamilan tersebut. Kelengkapan antenatal terdiri dari jumlah kunjungan antenatal dan kualitas pelayanan antenatal. Pelayanan antenatal mempunyai pengaruh yang 
baik terhadap pertumbuhan janin atau lama waktu mengandung, baik dengan diagnosis maupun dengan perawatan berkala terhadap adanya komplikasi kehamilan (PMKP No.97, 2014).

Pelayanan antenatal Ketika pertama kali ibu hamil termasuk Langkah yang snagat penting dilakukan, dengan demikian resiko kekurangan dan kehilangan bisa diatasi sedini mungkin. Upaya tersebut dilakukan saat pertama kali mengetahui adanya keterlambatan menstruasi, dengan demikian penetapan data dasar mempengaruhi tumbuh kembang janin dan Kesehatan ibu sampai persalinan. Ibu hamil juga dianjurkan untuk melakukan pengawasan antenatal minimal sebanyak 4 kali sesuai standar yang ditetapkan oleh pemerintah. Kualitas pelayanan antenatal meliputi sifat/struktur dan jenis pelayanan yang diberikan oleh tenaga kesehatan. Dalam hal ini pelayanan antenatal yang kontinu serta layanan antenatal yang ditujukan pada segmen kehamilan berisiko (Pengurus Pusat, 2006).

\section{Keikutsertaan Dalam Kegiatan Pertanian}

Berdasarkan hasil penelitian menunjukkan bahwa, dari responden yang mengalami kejadian BBLR, ada sejumlah 19 responden (63.3\%) dengan keikutsertaan dalam kegiatan pertanian $>3$ kali seminggu. Sedangkan pada kelompok responden yang tidak mengalami kejadian BBLR, ada sejumlah 25 responden $(27.8 \%)$ dengan keikutsertaan dalam kegiatan pertanian $>3$ kali seminggu. Dari hasil tersebut secara persentase, ibu dengan keikutsertaan dalam kegiatan pertanian > 3 kali dalam seminggu lebih banyak yang melahirkan bayi dengan BBLR dibandingkan dengan ibu yang melahirkan bayi tidak BBLR (BBLN). Hasil uji statistik hubungan antara keikutsertaan dalam kegiatan pertanian dengan kejadian BBLR diperoleh nilai $\mathrm{p}=0.002$ maka dapat disimpulkan ada hubungan yang signifikan antara keikutsertaan dalam kegiatan pertanian dengan kejadian BBLR.

Untuk mendapatkan nilai OR pada variabel keikutsertaan dalam kegiatan pertanian ini peneliti melakukan dummy antara ketiga kategori keikutsertaan dalam kegiatan pertanian dan berdasarkan tabel dummy tersebut diketahui bahwa nilai OR pada keikutsertaan dalam kegiatan pertanian $>3$ kali dalam seminggu lebih besar yaitu 4.491 dibandingkan dengan nilai OR pada keikutsertaan dalam kegiatan pertanian < 2 kali dalam seminggu yaitu sebesar 4.065 yang artinya ibu yang terlibat dalam kegiatan pertanian $>3$ kali dalam seminggu mempunyai risiko 5 kali untuk mengalami kejadian BBLR.

Penelitian ini selaras dengan penelitian yang dilakukan (Sari \& Hanani, 2013), yang menyatakan bahwa ada hubungan antara keterlibatan ibu hamil dalam kegiatan pertanian dengan kejadian BBLR. Hal ini dibuktikan dengan menggunakan uji Chi-Square yang menunjukkan nilai signifikansi sebesar 0.019. Begitu pula penelitian yang dilakukan oleh (Hidayati, 2013) dengan hasil uji statistik terhadap hubungan pekerjaan ibu dengan kejadian berat badan lahir rendah menunjukkan hubungan yang bermakna $(\mathrm{p}=0,005)$.

Kejadian BBLR ini dapat terjadi karena sebagian besar responden yang berada di Kecamatan Ketanggungan merupakan petani (52.2\%) subyek bekerja, dan 
juga dikarenakan sebagian besar ibu yang bekerja memiliki pekerjaan yang membahayakan kesehatan janinnya, terlibat dengan kegiatan yang berkaitan dengan bahan beracun yaitu pestisida pada bawang merah, selain itu ibu yang bekerja mempunyai pendidikan rendah sehingga mereka tidak dapat mengurangi faktor risiko dari pekerjaan mereka dengan melakukan pencegahan secara dini.

Seorang petani yang sedang hamil dan ikut menyemprotkan pestisida di sawah maka bisa terpapar pestisida tersebut, pencarian hama di ladang atau membantu mencabut rumput dari tanaman, Ketika ibu hamil mencucu pakaian yang terkena pestisida memungkinkan ibu hamil terpajan pestida tersebut. Begitupun Ketika waktu panen tiba, ibu hamil dapat terpajan pestisida dari daun bawang yang dipetiknya. Adanya pajanan pestisida dapat mengganggu pertumbuhan janin pada ibu hamil dan dapat mengakibatkan bayi lahir dalam keadaan berat badan lahir rendah.

Sementara penelitian di Tanzania menunjukkan bahwa ibu hamil yang bekerja memiliki risiko terjadinya BBLR 1,99 kali dibandingkan dengan ibu hamil yang tidak bekerja (ibu rumah tangga). Ibu hamil yang bekerja kecenderungan memiliki waktu istirahat kurang yang akan mengakibatkan terjadinya komplikasi kehamilan, seperti terlepasnya plasenta yang secara langsung berhubungan dengan BBLR (Setiyobudi, Setiani, \& Wahyuningsih, 2011).

Pekerjaan yang berkaitan dengan pestisida berpeluang besar untuk menimbulkan terjadinya keracunan pestisida. Pekerjaan ibu sewaktu hamil yang berkaitan dengan pestisida adalah pekerjaan sebagai petani yang bekerja di bidang pertanian. Pekerjaan di bidang pertanian berkaitan dengan sebagian besar petani menggunakan pestisida dalam menggarap lahan dan melindungi tanaman dari serangan hama. Petani yang melakukan pekerjaan berkaitan dengan pestisida akan menyebabkan mereka berpeluang menderita keracunan pestisida yang dapat masuk melalui hidung, mulut maupun kulit. Pada umumnya seorang petani kurang menyadari bahwa mereka terpapar pestisida yang dapat membahayakan kesehatan.

Walaupun pestisida merupakan zat racun, pestisida sering dianggap sesuatu hal biasa dan dihadapi sehari-hari. (Pujiono, 2009), menemukan bahwa terdapat hubungan yang signifikan antara pekerjaan pengelola pestisida dengan keracunan pestisida di tempat penjualan pestisida. Salah satu indikator terdapatnya keracunan pestisida dengan menurunnya aktivitas cholinesterase. Penelitian (Sundani \& SKM, 2017) menemukan terjadinya penurunan aktivitas cholinesterase pada pekerjaan penyemprotan pestisida. Lama paparan pestisida juga akan menurunkan aktivitas cholinesterase.

Selain lama pemaparan pestisida, frekuensi paparan pestisida sangat berkaitan dengan banyaknya pestisida yang masuk ke dalam tubuh. Semakin lama dan lebih dari tiga kali dalam seminggu serta berturut-turut seseorang terpapar dan semakin sering terpapar pestisida, maka akan semakin banyak pestisida yang terakumulasi di dalam tubuh. Hal ini disebabkan karena dengan lamanya terpapar, maka akan semakin banyak pestisida yang dapat melekat pada kulit, terhirup oleh 
hidung ataupun tertelan melalui mulut, sehingga pestisida akan masuk ke dalam tubuh dalam jumlah yang banyak.

\section{Lama Kerja}

Dari responden yang mengalami kejadian BBLR, ada sejumlah 21 responden (70\%) dengan lama kerja berisiko ( $\geq 5$ jam). Sedangkan pada kelompok responden yang tidak mengalami kejadian BBLR, ada sejumlah 34 responden (37.8\%) dengan lama kerja berisiko ( $\geq 5$ jam). Dari hasil tersebut secara persentase, ibu dengan lama kerja berisiko ( $\geq 5$ jam) lebih banyak yang melahirkan bayi dengan BBLR dibandingkan dengan ibu yang melahirkan bayi tidak BBLR (BBLN). Hasil uji statistik hubungan antara lama kerja dengan kejadian BBLR diperoleh nilai $\mathrm{p}=0.004$ maka dapat disimpulkan ada hubungan yang signifikan antara lama kerja dengan kejadian BBLR. Dari analisis diperoleh pula nilai $\mathrm{OR}=3.843$ (95\% CI; $1.579-9.355)$, dapat diartikan bahwa ibu yang bekerja $\geq 5$ jam sehari memiliki peluang melahirkan bayi dengan BBLR 3.843 kali dibandingkan dengan ibu yang bekerja $<5$ jam.

Hal ini sependapat dengan hasil penelitian Setiyobudi dkk. (2013), yang menyatakan bahwa, terdapat hubungan yang signifikan antara lama paparan pestisida dengan kejadian BBLR dengan nilai $\mathrm{p}=0$,001 dan RP 5,229 (95\% CI: 2,325 - 11,757). Penyebab adanya hubungan antara lama kerja dalam kegiatan pertanian dengan kejadian BBLR dikarenakan pada umumnya ibu terlibat langsung dengan aktivitas pertanian seperti mencari hama, mencabut rumput tanaman, menyiram tanaman, memanen, melepas bawang dari tangkainya, mencuci pakaian untuk bertani dan memupuk. Adanya kontak langsung antara ibu dengan pestisida menambah risiko pajanan pestisida yang berlebihan.

Menurut (Helen, 2001), seorang wanita hamil dengan aktivitas kerja yang berat berisiko mengalami persalinan prematur atau bayi dengan BBLR. Jenis pekerjaan juga dihubungkan dengan penghasilan yang dapat mempengaruhi pemenuhan kebutuhan gizi wanita hamil tersebut. Dari beberapa penelitian, persalinan prematur dan BBLR dapat terjadi pada wanita yang bekerja terus menerus selama kehamilan, terutama bila pekerjaan tersebut memerlukan kerja fisik atau berdiri untuk waktu yang lama. Keadaan ini dapat mempengaruhi pertumbuhan dan perkembangan serta kesejahteraan janin yang dikandungnya.

Semakin lama bekerja sebagai petani maka semakin sering kontak dengan pestisida sehingga risiko terjadinya keracunan pestisida semakin tinggi. Penurunan aktivitas kolinesterase dalam plasma darah karena keracunan pestisida akan berlangsung mulai seseorang terpapar hingga 2 minggu setelah melakukan kegiatan tersebut dan waktu yang dibutuhkan untuk dapat kontak dengan pestisida maksimal 5 jam per hari (Setiyobudi et al., 2011).

\section{Penggunaan Alat Pelindung Diri}

Pestisida masuk ke dalam tubuh dapat melalui berbagai cara, antara lain melalui pernafasan atau penetrasi kulit. Oleh karena itu cara-cara yang paling baik untuk mencegah terjadinya keracunan adalah memberikan perlindungan pada 
bagian-bagian tersebut. Peralatan untuk melindungi bagian tubuh dari pemaparan pestisida pada saat melakukan kegiatan pertanian disebut alat pelindung diri.

Berdasarkan hasil penelitian menunjukkan bahwa, dari responden yang mengalami kejadian BBLR, ada sejumlah 23 responden $(76.7 \%)$ dengan tidak menggunakan alat pelindung diri. Sedangkan pada kelompok responden yang tidak mengalami kejadian BBLR, ada sejumlah 46 responden $(51.1 \%)$ dengan tidak menggunakan alat pelindung diri. Dari hasil tersebut secara persentase, ibu dengan tidak menggunakan alat pelindung diri lebih banyak yang melahirkan bayi dengan BBLR dibandingkan dengan ibu yang melahirkan bayi tidak BBLR (BBLN). Hasil uji statistik hubungan antara penggunaan alat pelindung diri dengan kejadian BBLR diperoleh nilai $\mathrm{p}=0.025$ maka dapat disimpulkan ada hubungan yang signifikan antara penggunaan alat pelindung diri dengan kejadian BBLR. Dari analisis diperoleh pula nilai $\mathrm{OR}=3.143$ (95\% CI; 1.226-8.059) dapat diartikan bahwa, tidak menggunakan alat pelindung diri saat melakukan kegiatan pertanian memiliki peluang melahirkan bayi dengan BBLR 3.143 kali dibandingkan dengan ibu yang menggunakan alat pelindung diri saat melakukan kegiatan pertanian.

Hal ini sependapat dengan penelitian (Setiyobudi et al., 2011) yang menyatakan bahwa, terdapat hubungan yang signifikan antara pemakaian Alat Pelindung Diri (APD) dengan kejadian BBLR dengan nilai $\mathrm{p}=0,039$ dan $\mathrm{RP}=$ 2,699 (95\% CI : 1,180 - 6,174).

Berdasarkan hasil temuan di lapangan, kondisi ini ditunjang dengan tidak lengkapnya alat pelindung diri yang digunakan. Sebagian besar responden tidak menggunakan alat pelindung diri secara lengkap dan tidak memenuhi standar. Tidak lengkapnya penggunaan APD pada ibu hamil sewaktu bekerja di daerah pertanian akan meningkatkan pemaparan pestisida pada ibu hamil tersebut baik melalui hidung, mata dan kulit saat bekerja. Alat pelindung diri yang tidak lengkap akan memperlama waktu kontak pestisida dengan kulit sehingga absorpsi pestisida melalui kulit juga akan semakin banyak. (Pujiono, 2009) menemukan adanya hubungan yang signifikan antara pemakaian APD dengan Paparan Pestisida pada Masa Kehamilan keracunan pestisida dengan $P=0,012$. Pemakaian Alat Pelindung Diri (APD) yang tidak lengkap memungkinkan pestisida masuk ke dalam tubuh melalui kulit, saluran pernafasan, mata, dan mulut. Apabila pestisida tersebut terabsorpsi ke dalam tubuh maka akan mengakibatkan adanya gangguan hormon tiroid, yaitu hormon yang mengatur keseimbangan dengan hormon lainnya. Gangguan tersebut menyebabkan kelenjar tiroid tidak menghasilkan cukup banyak hormon tiroid sesuai yang dibutuhkan tubuh (hipotiroidisme) yang jika terjadi pada ibu hamil dapat mengganggu pertumbuhan dan perkembangan janin di dalam kandungannya (Sari \& Hanani, 2013).

\section{Faktor Dominan}

Berdasarkan hasil pemodelan terakhir analisis multivariate dalam penelitian ini menunjukkan bahwa variabel independen yang berhubungan signifikan secara statistik pada kejadian bayi dengan berat badan lahir rendah atau nilai $p$ value < 0.05 adalah variabel pengetahuan ibu, paritas, status gizi, Frekuensi pemeriksaan 
ANC dan lama kerja. Hasil Analisis multivariat menunjukkan bahwa variabel yang memiliki nilai signifikan yang tertinggi terhadap pada variabel lama kerja dengan nilai $p$ value 0.006 dan nilai OR sebesar 8.117. Artinya ibu dengan lama kerja lebih dari 5 jam dalam sehari memiliki peluang sebesar 8 kali untuk mengalami kejadian BBLR.

Berdasarkan survei yang dilakukan peneliti ketika melihat langsung pada saat penelitian di lapangan bahwa, kejadian ini dikarenakan pada umumnya ibu hamil terlibat langsung dengan aktivitas pertanian dan ini dilakukan oleh ibu lebih dari 5 jam sehari. Sebagian besar ibu bertani atau terlibat dalam pertanian mulai dari pagi sampai sore bahkan malam. Keterlibatan ibu hamil mulai dari menyiapkan bahan pestisida, terjun langsung ke sawah membantu suami bekerja seperti memanen, menyiram bawang, mengambil rumput di sawah dan mencuci pakaian suami setelah bekerja. Adanya kontak langsung antara ibu dengan pestisida menambah risiko pajanan pestisida yang berlebihan.

Dari beberapa penelitian, persalinan prematur dan BBLR dapat terjadi pada wanita yang bekerja terus menerus selama kehamilan, terutama bila pekerjaan tersebut memerlukan kerja fisik atau berdiri untuk waktu yang lama. Keadaan ini dapat mempengaruhi pertumbuhan dan perkembangan serta kesejahteraan janin yang dikandungnya.

Semakin lama bekerja sebagai petani maka semakin sering kontak dengan pestisida sehingga risiko terjadinya keracunan pestisida semakin tinggi. Penurunan aktivitas kolinesterase dalam plasma darah karena keracunan pestisida akan berlangsung mulai seseorang terpapar hingga 2 minggu setelah melakukan kegiatan tersebut dan waktu yang dibutuhkan untuk dapat kontak dengan pestisida maksimal 5 jam per hari (Setiyobudi et al., 2011).

Hal ini menunjukkan bahwa faktor yang paling dominan yang berhubungan dengan kejadian BBLR adalah faktor lama kerja.

\section{Kesimpula}

Setelah dilakukan penelitian tentang faktorfaktor yang berhubungan dengan kejadian berat badan lahir rendah pada petani bawang merah di Kecamatan Ketanggungan Kabupaten Brebes Provinsi Jawa Tengah Tahun 2017, maka dapat disimpulkan bahwa dari 120 ibu yang memiliki bayi umur $\leq 1$ tahun tanpa memandang usia kehamilan, sebagai kelompok kasus (BBLR) sejumlah $30 \mathrm{ibu}(25 \%)$ dan sebagai kelompok kontrol (tidak BBLR) sejumlah 90 ibu (75\%). Dari 11 faktor yang memiliki hubungan dengan kejadian BBLR, terdapat 5 faktor dominan yang berpengaruh untuk mengakibatkan ibu mengalami terjadinya BBLR, yaitu variabel pengetahuan ibu, paritas, status gizi ibu, Frekuensi pemeriksaan ANC dan lama kerja. Di antara 5 faktor tersebut, faktor lama kerja yang paling dominan berpengaruh terhadap kejadian BBLR di Kecamatan Ketanggungan Kabupaten Brebes, yaitu dengan nilai p value 0.006 dan nilai OR 8.117. Artinya ibu dengan lama kerja $\geq 5$ jam sehari memiliki peluang 8 kali untuk mengalami kejadian BBLR. 
Faktor-Faktor yang Berhubungan dengan Kejadian Berat Badan Lahir Rendah (BBLR)

\section{BIBLIOGRAFI}

Aliyu, M. H., Salihu, H. M., Keith, L. G., Ehiri, J. E., Islam, M. A., \& Jolly, P. E. (2005). Extreme parity and the risk of stillbirth. Obstetrics \& Gynecology, 106(3), 446-453.

Amalia, M. (2016). Analisis Perbedaan Berat Badan Aseptor KB Menggunakan Kontrasepsi Suntik Tiga Bulan. Syntax Literate; Jurnal Ilmiah Indonesia, 1(2), $1-15$.

Bobak, M., Dejmek, J., Solansky, I., \& Sram, R. J. (2005). Unfavourable birth outcomes of the Roma women in the Czech Republic and the potential explanations: a population-based study. BMC Public Health, 5(1), 106.

Damanik, D., \& Gorodetski, A. (2011). Spectral and quantum dynamical properties of the weakly coupled Fibonacci Hamiltonian. Communications in Mathematical Physics, 305(1), 221-277.

Depkes, R. I. (2007). Profil kesehatan 2007. Departemen Kesehtan RI.

Helen, F. (2001). Perawatan Maternitas. Jakarta: EGC, 60.

Hidayati, R. (2013). Modifikasi Tata Rias Pengantin Yogya-PAES AGENG. Gramedia Pustaka Utama.

Ismi Trihardiani, I. T. (2011). Faktor risiko kejadian berat badan lahir rendah di wilayah kerja Puskesmas Singkawang Timur dan Utara Kota Singkawang. Diponegoro University.

Manuaba, I., \& Bagus, G. (2007). Ilmu Penyakit Kebidanan, Kandungan dan Pelayanan KB untuk pendidikan Bidan. EGC, Jakarta.

Martaadisoebrata, D., Sastrawinata, S., \& Saifuddin, A. B. (2005). Bunga Rampai Obstetri dan Ginekologi Sosial. Jakarta: YBPSP.

Maryanti, D. (n.d.). dkk.(2011). Buku Ajar Neonatus, Bayi Dan Balita.

Negi, K. S., Kandpal, S. D., \& Kukreti, M. (2006). Epidemiological factors affecting low birth weight. JK Science, 8(1), 31-34.

Noor, N. N. (2008). Epidemiologi. Jakarta. Rineka Cipta Press.

Nurhadi, N. (2006). Faktor Risiko Ibu Dan Layanan Antenatal Terhadap Kejadian Bayi Berat Lahir Rendah (Studi kasus di BP RSUD Kraton Pekalongan). program Pascasarjana Universitas Diponegoro.

Nurrohmah, H. (2002). Hubungan Beberapa Faktor Maternal, Sosial Ekonomi Dan Pengetahuan Serta Praktek Tentang Antenatal Care (ANC) Dengan Kejadian 
Ika Popi Sundani

Berat Bayi Lahir Rendah (BBLR) Di Wilayah Kerja Puskesmas Kota Mungkid Kabupaten Magelang Januari 2001-Juni 2001. Diponegoro University.

Pantiawati, I. (2010). Bayi dengan BBLR (Berat Badan Lahir Rendah). Yogyakarta: Nuha Medika.

Pengurus Pusat, I. B. I. (2006). Standar pelayanan kebidanan. Jawa Barat.

Proverawati, A. (n.d.). dkk. 2010. Panduan Memilih Kontrasepsi.

Pujiono, P. (2009). Hubungan Faktor Lingkungan Kerja dan Praktek Pengelolaan Pestisida dengan Kejadian Keracunan Pestisida Pada Tenaga Kerja di Tempat Penjualan Pestisida di Kabupaten Subang. Program Pascasarjana Universitas Diponegoro.

Romauli, S. (2011). Buku Ajar Asuhan Kebidanan 1 Konsep Dasar Asuhan Kehamilan. Yogyakarta: Nuha Medika.

Sari, N. K., \& Hanani, D. (2013). Hubungan riwayat pajanan pestisida pada ibu hamil dengan kejadian berat badan lahir rendah (BBLR) di wilayah kerja puskesmas wanasari kabupaten brebes. Jurnal Kesehatan Masyarakat Universitas Diponegoro, 2(2), 18759.

Setiyobudi, B., Setiani, O., \& Wahyuningsih, N. E. (2011). Hubungan paparan pestisida pada masa kehamilan dengan kejadian berat badan bayi lahir rendah (BBLR) di Kecamatan Ngablak Kabupaten Magelang. Jurnal Kesehatan Lingkungan Indonesia, 12(1), 26-33.

Setyaningrum, S. R., Triyanti, T., \& Indrawani, Y. M. (2014). Pembelajaran di Pendidikan Anak Usia Dini dengan perkembangan kognitif pada anak. Kesmas: National Public Health Journal, 243-249.

Sistiarani, C. (2008). Faktor maternal dan kualitas pelayanan antenatal yang berisiko terhadap kejadian berat badan lahir rendah (BBLR) studi pada ibu yang periksa hamil ke tenaga kesehatan dan melahirkan di rsud banyumas tahun 2008. Program Pascasarjana Universitas Diponegoro.

Siwiendrayanti, A. (2011). Keterlibatan dalam aktivitas pertanian dan keluhan Kesehatan Wanita Usia Subur. KEMAS: Jurnal Kesehatan Masyarakat, 7(1), 73-82.

Soekanto, S. (2002). Sosiologi suatu pengantar Ringkas. Penerbit CV Rajawali Jakarta.

Sondari, W. D., SYAMSUR1PUTRA, A. A., \& Setiadi, T. (2006). Screening of alcohol-tolerant yeast of Saccharomyces Cerev/siae. J Teknlk Kimia Indonesia, $5(2), 409-414$.

Sundani, I. P., \& SKM, M. K. M. (2017). Faktor-Faktor Yang Berhubungan Dengan 
Faktor-Faktor yang Berhubungan dengan Kejadian Berat Badan Lahir Rendah (BBLR)

Kejadian Berat Badan Lahir Rendah (BBLR) Pada Petani Bawang Merah Di Kecamatan Ketanggungan Kabupaten Brebes Provinsi Jawa Tengah Tahun 2017. PLACENTA, 2(2), 41-56.

Syafitri, F. R., Sitawati, S., \& Setyobudi, L. (2014). Kajian etnobotani masyarakat desa berdasarkan kebutuhan hidup. Jurnal Produksi Tanaman, 2(2).

Winkjosastro, H. (2005). Ilmu Kebidanan, Edisi 2. Jakarta: Yayasan Bina Pustaka Sarwono Prawirohardjo. 